\title{
Pengaruh terapi oksigen hiperbarik terhadap jumlah kuman pada luka bakar derajat dua dalam dari hewan coba kelinci
}

\author{
${ }^{1}$ Taat Setiadi \\ ${ }^{1}$ Mendy Hatibie \\ ${ }^{1}$ Jan T. Ngantung \\ ${ }^{2}$ Luisa A. J. Wewengkang
}

\author{
${ }^{1}$ Bagian Bedah Fakultas Kedokteran Universitas Sam Ratulangi Manado \\ ${ }^{2}$ Bagian Mikrobiologi Fakultas Kedokteran Universitas Sam Ratulangi Manado \\ Email: taatse@gmail.com
}

\begin{abstract}
Management of wound has improved together with development of medical sciences, especially biomolecular science and traumatology. Wounds, especially burn wound is prone to edema and infection, associated with a lot of free radicals. Due to tissue edema, hypoxia and hypoperfusion occur. Exposure of high pressure oxygen increase gamma interferron (IFN- $\gamma$ ) which further induces nitric oxide synthase (i-NOS) and VEGF. Besides that, IFN- $\gamma$ increases the number of T helper 1 cells (TH-1) which influence B cells to produce IgG. Due to the increased IgG, the phagocytosis effect of leucocytes increase, therefore, it is assumed that hyperbaric oxygen therapy (HBO2) can reduce the degree of infected wound. This study aimed to analyze the effect of HBO2 on the numbers of bacteria in deep burn wound (2nd degree) in rabbits. This was a pure experimental study with a post test group design. Samples were 34 rabbits with deep burn wound (2nd degree) on their backs sized $2 \times 1 \mathrm{~cm}$. On day-5, bacteria cultures were obtained from all the wounds, and then the rabbits were divided randomly into 2 groups: treated with $\mathrm{HBO} 2$ and without; each group consisted of 17 rabbits. On day-10, the second bacteria cultures were done. The numbers of bacteria of the two groups were compared before and after $\mathrm{HBO}$. The results showed that distribution of bacteria in the two groups were as follows: Citrobacter freundii (34\%), Citrobacter difersus (32\%), Proteus vulgaris (13\%), Citrobacter mirabilis (10.5\%), and Staphylococcus aureus (10.5\%). The Mann-Whitney U test showed a significant difference in the number of bacteria between the 2 groups before and after treatment $(P<0.001)$. The treated group showed a decrease of bacteria number. Conclusion: Hyperbaric oxygen therapy could reduce the number of bacteria in burn wounds.
\end{abstract}

Keywords: burn wound, hyoperbaric oxyhen therapy, bacteria

\begin{abstract}
Abstrak: Paradigma penatalaksanaan luka berubah seiring dengan perkembangan ilmu kedokteran, khususnya bidang ilmu biomolekuler dan traumatologi. Dalam bidang luka, terutama luka bakar, bagian tubuh mengalami edema dan infeksi. Pada bagian ini ditemukan radikal bebas dalam jumlah besar. Akibat edema jaringan terjadi hipoksia karena hipoperfusi. Paparan oksigen tekanan tinggi menyebabkan peningkatan interferon gamma (IFN- $\gamma$ ) yang menginduksi nitric oxide synthase (i-NOS) dan VEGF. IFN- $\gamma$ meningkatkan sel T helper 1 (TH-1) yang memengaruhi sel B untuk menginduksi Ig-G. Dengan meningkatnya Ig-G, efek fagositosis dari leukosit juga akan meningkat, sehingga dapat diasumsikan bahwa hiperbarik mengurangi derajat infeksi pada luka. Penelitian ini bertujuan untuk menganalisis pengaruh terapi oksigen hiperbarik (TOH) terhadap jumlah kuman pada luka bakar derajat dua dalam pada hewan coba kelinci. Jenis penelitian ini eksperimental murni dengan desain post test kelompok. Penelitian dilakukan pada 34 kelinci yang diberikan luka bakar derajat dua dalam di daerah punggung dengan ukuran $2 \times 1 \mathrm{~cm}$. Pemeriksaan kultur kuman pada luka bakar dilakukan dua kali. Pada hari ke-5 diambil kultur dengan cara swab pada semua luka bakar di bagian punggung 34 kelinci, setelah itu kelinci dibagi secara acak menjadi dua kelompok yaitu yang menerima perlakuan TOH total 17 kelinci dan kelompok kontrol yang tidak menjalani TOH sebanyak 17 kelinci. Pada hari ke-10 setelah
\end{abstract}


menyelesaikan TOH dilakukan kultur kuman pada luka bakar dengan cara swab pada kedua kelompok. Jumlah bakteri dibandingkan pada kedua kelompok sebelum dan setelah pengobatan. Hasil penelitian memperlihatkan berdasarkan distribusi jenis kuman pada dua kelompok dalam penelitian ini ditemukan Citrobacter freundii (34\%), Citrobacter difersus (32\%), Proteus vulgaris (13\%), Citrobacter mirabilis (10,5\%), dan Staphylococcus aureus (10,5\%). Uji Mann-Whitney U menunjukkan perbedaan bermakna jumlah kuman antara kedua kelompok sebelum dan sesudah diberikan TOH dengan nilai $P<0,001$ di mana kelompok TOH menunjukkan penurunan jumlah kuman. Simpulan: TOH dapat mengurangi jumlah kuman pada luka bakar kulit.

Kata kunci: luka bakar, $\mathrm{TOH}$, kuman

Luka bakar derajat dua dalam adalah luka bakar yang ditandai dengan kerusakan menyeluruh lapisan epidermis dan dermis dan hanya menyisakan bagian sel basal folikel dan kelenjar keringat. Penyebab luka bakar derajat dua dalam selain terbakar api langsung atau tak langsung, juga bisa disebabkankarena pajanan suhu tinggi dari matahari, listrik, maupun bahan kimia. ${ }^{1}$

Proses penyembuhan luka bakar derajat dua dalam sama seperti proses penyembuhan luka pada umumnya yaitu melalui fase inflamasi, proliferasi, dan remodeling. ${ }^{2}$

Luka bakar terdiri dari beberapa derajat /tingkatan yaitu superficial burn, partial-thickness burn yang dibagi menjadi superficial dan deep, serta full-thickness burn. Derajat luka bakar ini tergantung dari suhu paparan, lamanya paparan, dan jenis kulit yang terpapar. Tingkat superficial burn tidak berpotensi menimbulkan jaringan parut sedangkan tingkat deep partial-thickness burn (luka bakar derajat dua) dan full thickness burn (luka bakar derajat tiga) sangat berpotensi menimbulkan jaringan parut. $^{3}$

Paradigma penatalaksanaan luka bakar mengalami perubahan seiring dengan perkembangan ilmu kedokteran, khususnya bidang ilmu biomolekuler dan traumatologi. Setiap fase luka bakar diwarnai oleh permasalahan spesifik dan perubahan yang dimaksud dirasakan sangat pesat sejak berkembangnya konsep Sistemic Inflamatory Response Syndrom (SIRS) dan Multi-system Organ Dysfunction Syndrome $(M O D S)$ serta traumatologi. Permasalahan yang dihadapi memerlukan pendekatan beberapa disiplin ilmu yang mutlak secara terpadu bersama-sama mengupayakan penurunan mortalitas luka bakar. ${ }^{4}$

Terapi oksigen hiperbarik (TOH) memodulasi nitrik oksida (NO) pada sel endotel. Pada sel endotel ini TOH juga meningkatkan vascular endothelial growth factor (VEGF). Melalui siklus Krebs terjadi peningkatan nikotinamida adenosin dinukleotida hidrogen (NADH) yang memicu peningkatan fibroblas yang diperlukan untuk sintesis proteoglikan dan bersama dengan VEGF akan memacu sintesis kolagen pada proses remodeling, yaitu salah satu tahapan dalam penyembuhan luka.

Mekanisme di atas berhubungan dengan salah satu manfaat utama TOH yaitu untuk penyembuhan luka. Pada bagian tubuh yang luka terdapat edema dan infeksi. Di daerah edema ini terdapat radikal bebas dalam jumlah yang besar. daerah edema ini mengalami kondisi hipooksigen karena hipoperfusi. Dengan pemaparan oksigen tekanan tinggi, terjadi peningkatan Interferon gamma (IFN- $\gamma$ ), inducible nitric oxide synthase (i-NOS) dan VEGF. IFN- $\gamma$ menyebabkan sel T helper 1 (TH-1) meningkat yang berpengaruh pada B-cell sehingga terjadi peningkatan Ig-G. Dengan meningkatnya Ig-G, efek fagositosis leukosit juga akan meningkat, sehingga dapat disimpulkan bahwa pada luka, hiperbarik berfungsi menurunkan infeksi dan edema. ${ }^{5}$

Saat ini $\mathrm{TOH}$ telah banyak dimanfaatkan, diantaranya untuk penderita luka bakar, decompression sickness, osteomielitis, dan ulkus atau gangren diabetikum. Mekanisme kerja TOH ialah dengan tekanan $\mathrm{O}_{2}$ yang melebihi 1 Atm akan menyebabkan peningkatan tekanan $\mathrm{O}_{2}$ pada jaringan, sehingga gradien difusi $\mathrm{O}_{2}$ 
ke dalam jaringan akan meningkat. Selain itu oksigen dapat larut dalam cairan darah secara fisika sehingga dapat dibawa ke daerah yang mengalami hipoksia. Oksigen yang larut tersebut akan keluar ke ekstravaskuler dan ruang intrasel dengan cara difusi dan kemudian digunakan oleh sel sehingga akan meningkatkan metabolisme enzimatik intrasel dan aktivitas penyembuhan luka akan meningkat. ${ }^{5,9-11}$

Penelitian ini bertujuan untuk menganalisis pengaruh TOH terhadap jumlah kuman luka bakar derajat dua dalam pada hewan coba kelinci dan juga menganalisis penggunaan $\mathrm{TOH}$ pada penyembuhan luka bakar dalam hal mengurangi komplikasi infeksi.

\section{METODE PENELITIAN}

Penelitian dilakukan di Laboratorium Mikrobiologi Fakutas Kedokteran Universitas Sam Ratulangi dan dilaksanakan mulai bulan Agustus sampai September 2015. Subjek penelitian ialah kelinci ternak (Oryctalagus cuniculus). Kriteria inklusi ialah kelinci telah mendapat sertifikat bebas penyakit dari Dinas Peternakan, jenis kelamin jantan, berusia $>12$ minggu, berat badan 2000-2500 g, dan mendapatkan jumlah dan jenis diet yang sama. Kriteria eksklusi ialah kelinci yang mengalami cedera organ lain saat dilakukan penelitian. Kriteria drop out ialah kelinci yang mati selama penelitian.

Prosedur penelitian ialah kelinci dikarantina dalam kandang di Laboratorium Riset Fakultas Kedokteran Universitas Sam Ratulangi Manado. Pada daerah punggung kelinci dibuat luka bakar derajat dua dalam seluas $2 \times 1 \mathrm{~cm}$ dengan cara menempelkan selama 6 detik sebuah lempeng besi yang telah dipanaskan selama 3 menit dalam api. Sebelumnya kelinci diberikan premedikasi diazepam 1 $\mathrm{mg} / \mathrm{kgBB}$ intramuskular pada otot paha dan bokong. Sebagai anastesi umum diberikan ketamine hydrochloride $40 \mathrm{mg} / \mathrm{kgBB}$ intramuskular pada otot paha lainnya. Kultur dilakukan pada hari ke-5 dengan cara $s w a b$ lalu diperiksa di Laboratorium
Mikrobiologi Fakultas Kedokteran Universitas Sam Ratulangi Manado.

Sampel dibagi menjadi dua kelompok yaitu kelompok yang diberi perlakuan $\mathrm{TOH}$ dan yang tidak diberi perlakuan $\mathrm{TOH}$. Kelompok perlakuan diberikan $\mathrm{TOH}$ pada hari ke-5 (langsung setelah dilakukan swab) selama 6 hari berturut-turut. Pada kedua kelompok dilakukan kultur kuman lagi dengan cara swab pada hari ke-10 lalu diperiksa di laboratorium yang sama. Analisis data dilakukan pada kedua kelompok.

\section{HASIL PENELITIAN}

Hasil penelitian ini mendapatkan perbedaan jumlah pertumbuhan kuman hari ke-5 (sebelum perlakuan $\mathrm{TOH}$ ) dan hari ke10 (setelah perlakuan $\mathrm{TOH}$ ) pada kedua kelompok (Tabel 1). Dari hasil kultur kedua kelompok pada penelitian ini didapatkan Citrobacter freundi (34\%), Citrobacter difersus (32\%), Proteus vulgaris (13\%), Citrobacter mirabilis (10,5\%), dan Staphylococcus aureus (10,5\%). Dari jenis kuman yang ditemukan ternyata tidak terdapat perbedaan bermakna antara kedua perlakuan.

Pada Tabel 2 dapat dilihat bahwa jenis kuman Gram negatif jauh lebih banyak daripada Gram positif pada kedua perlakuan.

Pada Tabel 3 dapat dilihat bahwa jumlah kuman yang meningkat merupakan persentase tertinggi.

Pengujian perbedaan jumlah kuman pada hari ke-5 dapat dilihat pada Tabel 5.

Pengujian kenormalan data jumlah kuman yang ditemukan pada hari ke-5 dilakukan dengan tes Kolmogorov-Smirnov (Tabel 6 ).

Pada Tabel 4 dapat dilihat bahwa jumlah kuman yang menurun merupakan persentase tertinggi.

Dari hasil pengujian didapatkan data jumlah kuman pada kedua perlakuan tidak menyebar normal $(P<0,05)$ dan dilanjutkan dengan uji Mann-Whitney U.

Pada uji Mann-Whitney U secara statistik didapatkan bahwa tidak terdapat 
perbedaan bermakna jumlah kuman pada kedua perlakuan pada hari ke-5 $(P=$ $0,408)$.

Tabel 1. Distribusi jenis kuman pada kedua kelompok

\begin{tabular}{lcc}
\hline \multicolumn{1}{c}{ Jenis kuman } & \multicolumn{2}{c}{ Perlakuan } \\
& TOH & Tanpa TOH \\
\hline Citrobacter freundii & 6 & 7 \\
Citrobacter diversus & 7 & 5 \\
Proteus vulgaris & 2 & 3 \\
Staphylococcus aureus & 2 & 2 \\
Citrobacter mirabilis & 2 & 2 \\
\hline
\end{tabular}

Tabel 2. Distribusi jumlah kuman gram negatif dan positif pada kedua perlakuan

\begin{tabular}{lcc}
\hline Gram & \multicolumn{2}{c}{ Perlakuan } \\
& TOH & $\begin{array}{c}\text { Tanpa } \\
\text { TOH }\end{array}$ \\
\hline Gram Negatif & 17 & 17 \\
Gram positif & 2 & 2 \\
Total & 19 & 19 \\
\hline
\end{tabular}

Tabel 3. Perbandingan jumlah kuman hari ke5 dengan ke-10 pada kelompok perlakuan tanpa $\mathrm{TOH}$

\begin{tabular}{lcc}
\hline $\begin{array}{l}\text { Jumlah } \\
\text { kuman }\end{array}$ & $\begin{array}{c}\text { Jumlah } \\
\text { sampel }\end{array}$ & Persentase \\
\hline Meningkat & 11 & 58 \\
Menurun & 1 & 5 \\
Tetap & 7 & 37 \\
Total & 19 & 100 \\
\hline
\end{tabular}

Tabel 4. Perbandingan jumlah kuman pada hari ke-5 dengan hari ke-10 pada kelompok perlakuan dengan $\mathrm{TOH}$

\begin{tabular}{lcc}
\hline $\begin{array}{l}\text { Jumlah } \\
\text { kuman }\end{array}$ & $\begin{array}{c}\text { Jumlah } \\
\text { sampel }\end{array}$ & Persentase \\
\hline Meningkat & 0 & 0 \\
Menurun & 13 & 69 \\
Tetap & 6 & 31 \\
Total & 19 & 100 \\
\hline
\end{tabular}

Tabel 6. Tes kenormalan data KolmogorovSmirnov

Kolmogorov Smirnov

\begin{tabular}{lccc}
\hline Perlakuan & Statistik & df & $P$ \\
TOH & 424 & 19 &, 000 \\
Tanpa TOH & 389 & 19 &, 000 \\
\hline
\end{tabular}

Tabel 7. Hasil uji Mann-Whitney U hari ke-5

\begin{tabular}{lcc}
\hline Perlakuan & Rerata & $\begin{array}{c}\text { Uji } \\
\text { Mann-Whitney } \\
\text { U }\end{array}$ \\
\hline TOH & 19,89 & $P=0,408$ \\
Tanpa TOH & 19,11 & \\
\hline
\end{tabular}

\section{Pengujian perbedaan jumlah kuman hari ke-5}

Tabel 5. Nilai statistik deskriptif jumlah kuman hari ke-5

\begin{tabular}{ccccccc}
\hline Perlakuan & N & Minimum & Maksimum & Median & Rerata & $\begin{array}{c}\text { Simpangan } \\
\text { baku }\end{array}$ \\
\hline Kontrol & 19 & 1000 & 100000 & 10000,00 & 34632,58 & 45777,494 \\
TOH & 19 & 1000 & 100000 & 10000,00 & 30842,11 & 42643,566 \\
Total & 38 & 1000 & 100000 & 10000,00 & 32736,84 & 43678,608 \\
\hline
\end{tabular}




\section{Pengujian perbedaan jumlah kuman hari ke-10}

Tabel 8. Nilai statistik deskriptif jumlah kuman hari ke-10

\begin{tabular}{lcllccl}
\hline Kelompok & N & Minimum & Maksimum & Median & Rerata & $\begin{array}{c}\text { Simpangan } \\
\text { baku }\end{array}$ \\
\hline Kontrol & 19 & 1000 & 100000 & 10000,00 & 51684,21 & 47168,790 \\
TOH & 19 & 1000 & 10000 & 1000,00 & 1947,37 & 2837,716 \\
Total & 38 & 1000 & 100000 & 10000,00 & 26815,79 & 41490,380 \\
\hline
\end{tabular}

Pengujian kenormalan data jumlah kuman yang ditemukan pada hari ke-10 dilakukan dengan tes Kolmogorov-Smirnov (Tabel 9).

Tabel 9. Tes kenormalan data Kolmogorov Smirnov

\begin{tabular}{lccc}
\hline Perlakuan & \multicolumn{3}{c}{ Kolmogorov Smirnov } \\
& Statistik & df & P \\
\hline TOH & 338 & 19 &, 000 \\
Tanpa TOH & 525 & 19 &, 000 \\
\hline
\end{tabular}

Dari hasil pengujian didapatkan jumlah kuman pada kedua perlakuan data tidak menyebar normal $(P<0,05)$ dan diuji lanjut dengan uji Man-Whitney U (Tabel 10).

Tabel 10. Hasil uji Mann-Whitney U hari ke10

\begin{tabular}{lcc}
\hline Perlakuan & Rerata & $\begin{array}{c}\text { Uji } \\
\text { Mann-Whitney U }\end{array}$ \\
\hline TOH & 11,57 & $P<0,001$ \\
Tanpa TOH & 27,47 & \\
\hline
\end{tabular}

Hasil uji Mann-Whitney U mendapatkan perbedaan jumlah kuman yang sangat bermakna antara kedua perlakuan pada hari ke-10 $(P<0,001)$.

\section{BAHASAN}

Dari hasil penelitian yang telah dilakukan ternyata kuman yang tumbuh pada luka bakar kulit kelinci lebih banyak kuman Gram negatif daripada Gram positif dengan perbandingan $89 \%: 11 \%$. Jenis kuman yang ditemukan didominasi oleh kuman Gram negatif seperti Citrobacter freundi (34\%), Citrobacter difersus (32\%), Proteus vulgaris (13\%), Citrobacter mirabilis (10,5\%), dan kuman Gram positif seperti Staphylococcus aureus (10,5\%).

Hal ini sesuai dengan pernyataan Moenadjat ${ }^{4}$ bahwa kolonisasi Gram positif yang paling banyak dalam 3-5 hari pasca luka bakar. Kuman Gram negatif nanti muncul pada hari 5-10 setelah terjadinya luka. Pada hari ke 3-5, luka didominasi oleh kuman Gram positif yang berasal dari apendises kulit dan populasi kuman baru digantikan oleh kuman gram negatif setelah 5-10 hari.

Dari distribusi kuman yang ditemukan pada penelitian ini ternyata kuman yang tumbuh pada hasil biakan semuanya bersifat aerob yaitu kuman yang bisa hidup dengan adanya oksigen. Jenis kuman citrobacter merupakan kuman patogen yang hidup di lingkungan tanah, air, serta saluran pencernaan manusia dan hewan. Citrobacter dapat menginfeksi saluran pernafasan, saluran pencernaan, darah, dan tempat-tempat yang tidak steril pada tubuh manusia maupun hewan. Jenis kuman lain yang ditemukan ialah proteus dan staphylococcus. Jenis kuman proteus juga dapat menginfeksi saluran pernafasan dan pencernaan. Kuman staphylococcus dapat menjadi penyebab infeksi baik pada manusia maupun hewan, dan kuman ini dapat menginfeksi setiap jaringan ataupun alat tubuh termasuk kulit dengan tanda yang khas seperti peradangan, nekrosis, dan pembentukan abses. ${ }^{23,24}$

TOH dapat meningkatkan jumlah oksigen yang terlarut dalam darah; hal ini menyebabkan peningkatan oksigen yang 
dilepaskan di daerah yang terlibat dalam sirkulasi plasma darah sehingga dapat mengurangi hipoperfusi pada daerah luka yang mengalami edema dan vasokonstriksi. ${ }^{13}$

Pada penelitian ini tidak ditemukan adanya kuman yang bersifat anaerob pada biakan sehingga peneliti tidak bisa melaporkan pengaruh $\mathrm{TOH}$ terhadap pertumbuhan kuman yang sifatnya anaerob. Hal ini mungkin dikarenakan luka bakar merupakan luka terbuka sehingga terdapat hubungan antara luka dengan udara luar yang mengandung oksigen sehingga tidak ada kuman anaerob yang ditemukan pada luka bakar dalam penelitian ini. Kuman aerob yang ditemukan pada penelitian ini ternyata jumlahnya menurun setelah diberikan $\mathrm{TOH}$. Hal ini dapat menerangkan bahwa TOH juga dapat memberikan efek menurunkan jumlah kuman yang bersifat aerob. Hal ini dikarenakan selain memberikan efek meningkatkan perfusi oksigen ke daerah luka, TOH juga dapat berfungsi sebagai bakterisid melalui peningkatan efek fagositosis dari leukosit PMN karena selsel ini membutuhkan oksigen untuk menjalan-kan fungsinya dalam hal fagositosis dan pemusnahan bakteri.

Menurut Moenadjat ${ }^{4}$ agen penyebab infeksi luka bakar pada kulit manusia diantaranya ialah kuman Gram negatif seperti Pseudomonas aeruginosa, Escherichia coli, Klebsiella pneumonia, Enterobacter cloacae, dan Gram positif seperti Streptococcus, Staphylococcus dan Enterococcus. ${ }^{4}$ Jika dibandingkan hasil penelitian dan kepustakaan yang ada terdapat perbedaan jenis kuman Gram negatif yang dapat menjadi agen penyebab infeksi luka bakar pada kulit manusia dan pada kulit kelinci sedangkan jenis kuman Gram positif cenderung sama.

Hasil pengambilan sampel pada hari ke-10 yaitu setelah kelompok perlakuan diberi TOH memperlihatkan perbedaan yang sangat bermakna terhadap jumlah kuman pada kedua kelompok dimana terjadi penurunan jumlah kuman pada kelompok yang mendapat perlakuan $\mathrm{TOH}$. Hal ini dibuktikan dengan uji Mann-
Whitney $\mathrm{U}$ yaitu menunjukkan nilai $P<$ 0,001 .

Data penelitian ini memberikan suatu gambaran bahwa $\mathrm{TOH}$ merupakan salah satu faktor yang dapat memengaruhi pengurangan jumlah kuman patogen. Hal ini dapat dilihat dengan berkurangnya jumlah kuman setelah mendapat perlakuan TOH. Dengan demikian $\mathrm{TOH}$ dapat menjadi salah satu faktor yang berperan dalam mengurangi infeksi pada luka bakar karena bila kondisi luka terkontaminasi oleh kuman dalam jumlah relatif besar maka kemungkinan risiko infeksi juga makin besar.

Hal diatas sesuai dengan acuan pustaka bahwa $\mathrm{TOH}$ bekerja dengan meningkatkan tekanan $\mathrm{O}_{2}$ pada jaringan sehingga gradien difusi $\mathrm{O}_{2}$ ke dalam jaringan akan meningkat. Meningkatnya pasokan oksigen dapat meningkatkan efek bakterisidal leukosit PMN yang membutuhkan oksigen untuk fagositosis dan pemusnahan bakteri. Bila tekanan $\mathrm{O}_{2}$ menurun, efisiensi aksi bakterisidal leukosit PMN menurun secara drastis sehingga risiko infeksi semakin tinggi.

\section{SIMPULAN}

Dari hasil penelitian dan bahasan dapat disimpulkan bahwa jenis kuman yang paling banyak ditemukan ialah kuman Gram negatif Citrobacter freundii dan Citrobacter diversus.

Pemberian terapi oksigen hiperbarik dengan tekanan tertentu dapat menurunkan jumlah kuman pada kulit yang mengalami luka bakar.

\section{SARAN}

1. Penelitian ini kiranya dapat menjadi bahan pertimbangan untuk melakukan penelitian lebih lanjut pada manusia dalam hal pengaruh terapi oksigen hiperbarik terhadap penyembuhan luka bakar.

2. Perlu dilakukan uji pengaruh terapi oksigen hiperbarik terhadap kuman dengan variasi yang lebih banyak. 


\section{DAFTAR PUSTAKA}

1. Xiang XR. Burn Regenerative Medicine and Therapy. Tokyo: Karger, 2004; p. 21-5.

2. Sjamsuhidajat $R$. Luka dan penyembuhan luka. In: Buku Ajar Ilmu Bedah (Edisi revisi). Jakarta: EGC, 1997; p. 72-97.

3. Klien MB. Thermal, electrical and chemical injury. In: Plastic Surgery Grabb \& Smiths (6th ed). Philadelphia: Lippincott William \& Wilkins, 2007; p. 132-4.

4. Moenadjat Y. Petunjuk Praktis Penatalaksanaan Luka Bakar. Jakarta: Asosiasi Luka Bakar Indonesia, 2005; p. 1.

5. Mathieu D, Wattel F. Handbook on Hyperbaric Medicine. France: Springer, 2006; p. 1-34, 103-16.

6. An European Code of Good Practice for Hyperbaric Oxygen Therapy, prepared by Working Group (safety of the best action) B14. HBO, 2004.

7. Christ DL, Caroline O. Hyperbaric Oxygen Therapy: A Rapid Assesment KCE report. Vol 74. Belgia, 2008.

8. Kawasima M. Tamura H, Nagayoshi I, Takao K, Yoshida K, Yamaguchi T. et al. Hyperbaric oxygen therapy in orthopedic conditions. Undersea Hyperb Med. 2004;31(1):155-62.

9. Matsuda T, Hasegawa Y, Kataoka Y, Iwata H, Miura T, Takahashi H. The effect of hyperbaric oxygenation on bone in spontaneously hypertensive rats. Acta Orthopaedica Scandinavica. 1993;64 (1):41-3.

10. Simpson BG. The structure and physiology of bone and physiotherapeutic modalities to promote fracture healing. Available from: http://physioclinic.net/ wp-content/ uploads/2015/04/Thestructure-and-physiology-of-bone-andphysiotherapeutic-modalities-topromote-fracture-healing.pdf. 1997; p. 847-50.

11. Wu D, Malda J, Crawford R, Xiao Y. Effect of hyperbaric oxygenation on proliferation and differentiation of osteoblasts from human alveolar bone. Connect Tissue Res. 2007;48:206-13.

12. Shahriari A, Khooshideh M, Heidari M. Diseases treated with hyperbaric oxygen therapy; a literature review. Med Hypothesis Discov Innov Interdisciplinary. 2014;1(2):1-9.
13. Gill AL, Bell CNA. Hyperbaric oxygen: its uses, mechanisms of action and outcomes. QJ Med. 2004;97:385-93

14. Murphy PS, Evans GRD. Advances in wound healing: A review of current wound healing products. Hindawi publishing corporation. USA. 2012. Volume 2012. Pgs : 1-6

15. Villanueva E, Bennett MH, Wasiak J, Lehm JP. Hyperbaric oxygen therapy for thermal burns (Cochrane review). Oxford: The Cochrane Library Issue 1, 2006.

16. Baranoski S, Ayello EA, editors. Wound Care Essentials: Practice Principles (2nd ed). Philadelphia: Lippincott Williams \& Wilkins, 2008; p. 156-7.

17. Kryger Zol B, Sisco M. Burns: Initial Management and Resuscitation. In: Practical Plastic Surgery. Austin: Lande Bioscience, 2007; p. 155.

18. Gentur S. Luka bakar. In: Petunjuk Praktis Ilmu Bedah Plastik Rekonsruksi (1st ed). Jakarta: Yayasan Khasanah Kebajikan, 2007; p.80-2.

19. Friedstat J. Burns. In: Brunicardi F, Andersen D, Billiar T, editors. Schwartzs Principles of Surgery (10th ed). New York: McGraw-Hill Education. 2014; p. 227-9.

20. Brown DL, Borscel GH. Burns. In: Michigan Manual of Plastic Surgery (1st ed). Philadelphia: Lippincott Williams \& Wilkins, 2004; p. 381-2.

21. Perdanakusuma DS. Skin Grafting. Surabaya: Airlangga University Press, 1998; p. 3-9.

22. Chaspuri D. Perbandingan epitelialisasi kulit kelinci pada luka bakar derajat dua dalam antara pemberian moist exposed burn ointment dan silver-sulfadiazine [Karya akhir]. Manado Universitas Sam Ratulangi; 2011.

23. Wang JT, Chang SC, Chen YC, Luh KT. Comparison of antimicrobial susceptibiliy of Cirobacer freundii isolaes in two different time periods. $\mathrm{J}$ Microbiol, Immunol Infect. 200 Dec;258-62

24. Whalen JG, Mully TW, English JC 3rd. Spontaneous Citrobacter freundii infection in an immunocompetent patient. Arch Dermatol. 2007;143(1):124-5. 